\title{
Comparative evaluation of antimicrobial efficacy of an alternative natural agent for disinfection of toothbrushes
}

\author{
R. Vignesh ${ }^{1}$, C. Vishnu Rekha ${ }^{1}$, Parisa Norouzi Baghkomeh $^{1}$, Sankar Annamalai $^{1}$, \\ Ditto Sharmin ${ }^{1}$
}

Correspondence: Dr. R. Vignesh

Email: dhanam61@yahoo.co.in
'Department of Pediatric and Preventive Dentistry, Meenakshi Ammal Dental College and Hospital, Chennai, Tamil Nadu, India

\section{ABSTRACT}

Objective: The aim of this study was to assess the antimicrobial potency of aqueous extract of Psidium guajava leaves in two different concentrations as a toothbrush disinfectant against three oral bacterial species. Materials and Methods: Aqueous extracts of $P$. guajava leaves were prepared at $20 \%$ and $30 \%$ concentrations and $0.2 \%$ chlorhexidine was used as control. The toothbrushes were equally divided into 9 groups with 10 toothbrushes per disinfectant, which were contaminated with Streptococcus mutans, Lactobacillus acidophilus, and Enterococcus faecalis. Microbial culture was done after $5 \mathrm{~min}$ and $3 \mathrm{~h}$ of decontamination. Results: Group Ia and Ib showed that the presence of E. faecalis was observed in $8(40 \%)$ of 20 toothbrushes. Group IIa and IIb showed a significant reduction in colony forming unit/toothbrush during $3 \mathrm{~h}$ evaluation. Group IIIa and IIIb showed nil growth during $3 \mathrm{~h}$ evaluation. Nil growth was observed with the control group for all three organisms. Statistically significant values were obtained for $5 \mathrm{~min}(P<0.001)$ and $3 \mathrm{~h}(P<0.001)$ disinfection period against L. acidophilus at two different concentrations. Conclusion: Aqueous extracts of guava leaves can be used as an alternative organic product for disinfection of toothbrushes.

Key words: Guava, toothbrush, Streptococcus mutans

\section{INTRODUCTION}

Oral diseases can be controlled through proper oral hygiene by reducing the microbial load. ${ }^{[1]}$ Although toothbrushes are free from microorganisms after the manufacturing process, they become contaminated on regular usage. ${ }^{[2,3]}$ Although rinsing with tap water is the common disinfecting protocol, it resulted in continued high levels of contamination. ${ }^{[4]}$ Psidium guajava has high level of antibacterial activity ${ }^{[5]}$ and preferred to use as a mouth rinse by Kraivaphan et al. and Esimone et al. ${ }^{[6,7]}$ However, there is minimal information on its use as toothbrush disinfectant. This study was aimed to assess the antimicrobial potency

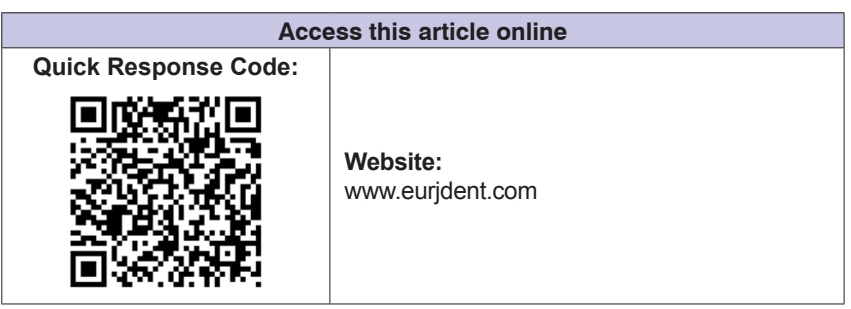

of aqueous extract of $P$. guajava leaves in two different concentrations as a toothbrush disinfectant against three oral bacterial species.

\section{MATERIALS AND METHODS}

Study products

One hundred Colgate ${ }^{\circledR}$ junior toothbrushes with standardized dimensions, bristles, and color were obtained. They were taken from their original packages and were autoclaved before its use. The

This is an open access article distributed under the terms of the Creative Commons Attribution-NonCommercial-ShareAlike 3.0 License, which allows others to remix, tweak, and build upon the work non-commercially, as long as the author is credited and the new creations are licensed under the identical terms.

For reprints contact: reprints@medknow.com

How to cite this article: Vignesh $\mathrm{R}$, Rekha CV, Baghkomeh PN, Annamalai S, Sharmin D. Comparative evaluation of antimicrobial efficacy of an alternative natural agent for disinfection of toothbrushes. Eur J Dent 2017;11:111-6.

DOI: 10.4103/ejd.ejd_196_16 
brushes were then kept in nutrient broth covering the bristles and incubated for $24 \mathrm{~h}$ at $37^{\circ} \mathrm{C}$ to check for sterility. Ten toothbrushes with turbid broth suggesting contamination were discarded from the study.

\section{Test organisms}

Streptococcus mutans (Microbial Type Culture Collection [MTCC] 890), Lactobacillus acidophilus (MTCC 495), and Enterococcus faecalis (MTCC 439) were obtained from (MTCC) gene bank, Chandigarh, India. The revival of bacteria was done using nutrient broth kept in an incubator at $37^{\circ} \mathrm{C}$ for $24 \mathrm{~h}$. Standardized suspensions of these strains were made at $0.5 \mathrm{McF}$ arland scale and 30 toothbrushes per organism were immersed into the suspensions and incubated at $37^{\circ} \mathrm{C}$ for $10 \mathrm{~min}$.

\section{Preparation of extract}

The plant specimen (leaves of $P$. guajava) was collected from botanical garden in Anna Nagar, Chennai. The leaves were cleaned and shade dried for 1 week at room temperature. Then, the leaves were weighed and stored in air tight bottles. The dried leaves were grounded to powder form and were sieved. Aqueous extracts were prepared in the Central Research Laboratory, Meenakshi Ammal Dental College and Hospital, Chennai, India. The procedure of aqueous decoction followed to prepare the extracts was based on a previous study by Pai et al. ${ }^{[8]}$ Decoctions were prepared by boiling $10 \mathrm{~g}$ of the powder in $100 \mathrm{ml}$ sterile distilled water over a low flame for $15 \mathrm{~min}$. The flasks were then plugged and allowed to cool for $45 \mathrm{~min}$. After cooling, the contents were filtered with Whatman's filter paper. Each extract was then diluted with sterile water to obtain two different concentrations of $20 \%$ and $30 \%$ and stored in refrigerator until use. $0.2 \%$ chlorhexidine gluconate was taken as control.

\section{Disinfection and microbial analysis}

Ten toothbrushes were used under each test organism for each disinfectant [Figure 1]. The toothbrushes were immersed into test tubes containing the disinfectant solutions covering up to the bristle head and kept in incubator for $5 \mathrm{~min}$ at $37^{\circ} \mathrm{C}$. An aliquot was taken using a pipette and streaked using nichrome loop over a brain-heart infusion agar plate for culturing and placed in an incubator at $37^{\circ} \mathrm{C}$ for $24 \mathrm{~h}$. The same procedure was repeated after $3 \mathrm{~h}$ disinfection period. After $24 \mathrm{~h}$ incubation, the agar plates were subjected to colony counting procedure using the stereo microscope under reflected light and the number of colony forming unit per toothbrush (cfu/toothbrush) was recorded by a blinded examiner.

\section{Statistical analysis}

Kruskal-Wallis test was done to compare the cfu/ toothbrush using the disinfectants for all the test microorganisms. Bonferroni-corrected MannWhitney test was done for pairwise comparison and Wilcoxon signed-rank test was done to compare between time points. A $P<0.05$ is considered as statistically significant.

\section{RESULTS}

In Group Ia and Ib, during the first (after $5 \mathrm{~min}$ ) and second (after $3 \mathrm{~h}$ ) evaluation, the presence of E. faecalis was observed in eight (40\%) of 20 toothbrushes with number of colonies ranging from 10 to 100. In Group IIa and IIb, during the first evaluation, the presence of L. acidophilus was observed in all toothbrushes with number of colonies ranging from 50,000 to >100,000; however, in second evaluation, the number of cfu reduced significantly. In Group IIIa and IIIb, during the first evaluation, nil growth of $S$. mutans was observed in $16(80 \%)$ of 20 toothbrushes and all 20 toothbrushes $(100 \%)$ showed nil growth by the end of second evaluation. In Group Ic, IIc, and IIIc where $0.2 \%$ chlorhexidine was used, nil growth of all microorganisms was observed by the end of both first and second evaluation [Figure 2-4].

On comparing the concentration of the disinfectants in all the groups, statistically significant values were obtained for $5 \mathrm{~min}(P<0.001)$ and $3 \mathrm{~h}(P<0.001)$ disinfection period against L. acidophilus. Group IIb showed a significant reduction in microbial load than Group IIa. Group Ib and IIIb showed a considerable reduction of microbial load than Group Ia and IIIa, but they were not statistically significant at both time intervals $(P>0.001)$ [Table 1$]$.

When compared between the disinfection period, there was statistically significant reduction of L. acidophilus

\begin{tabular}{|c|c|c|c|c|}
\hline Variable & $\begin{array}{c}\text { Concentration } \\
\text { level }\end{array}$ & $n$ & Mean rank & $P$ \\
\hline \multirow[t]{3}{*}{ L. acidophilus (5 min) } & $20 \%$ & 10 & 22.70 & $<0.001$ \\
\hline & $30 \%$ & 10 & 18.30 & \\
\hline & Control & 10 & 5.50 & \\
\hline \multirow[t]{3}{*}{ L. acidophilus (3 h) } & $20 \%$ & 10 & 23.40 & $<0.001$ \\
\hline & $30 \%$ & 10 & 17.60 & \\
\hline & Control & 10 & 5.50 & \\
\hline
\end{tabular}


Vignesh, et al.: Guava leaf extract as toothbrush disinfectant

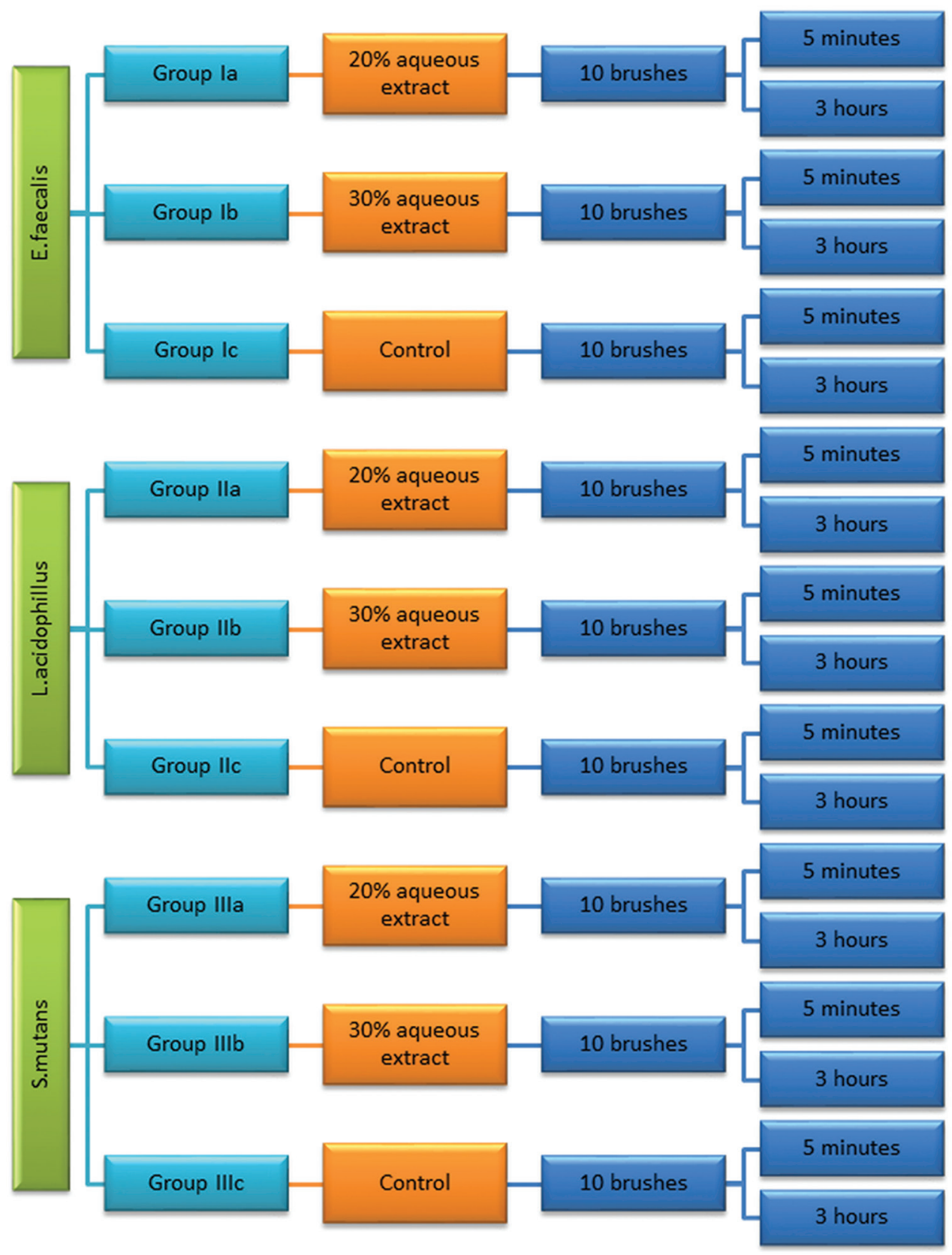

Figure 1: Flow chart explaining the distribution of groups

from $5 \mathrm{~min}$ to $3 \mathrm{~h}$ for both Group IIa $(P=0.027)$ and Group IIb $(P=0.011)$ while other groups did not show statistically significant values [Table 2].

On pairwise comparison, both Group IIa and Group IIb gave a statistically significant reduction of L. acidophilus similar to Group IIc ( $0.2 \%$ chlorhexidine) [Table 3].

\section{DISCUSSION}

In the present in vitro study, there was nil growth of the three test organisms in the group of toothbrushes disinfected for $5 \mathrm{~min}$ and $3 \mathrm{~h}$ in Group Ic, IIc, IIIc which were disinfected with $0.2 \%$ chlorhexidine gluconate. This result shows that the methodology is correct and it can be used as a positive control in in vitro tests to evaluate the efficacy of different disinfection protocols. We accept with Moshrefi that chlorhexidine solution is the "gold standard" antimicrobial, compared to other agents used for dental biofilm control. ${ }^{[9]}$

Although various studies evaluated the efficacy of antimicrobial activity of guava leaves against common oral pathogens, ${ }^{[10,11]}$ the present study evaluated its antibacterial efficacy in toothbrushes. The necessity for taking aqueous extracts for the study is because it 


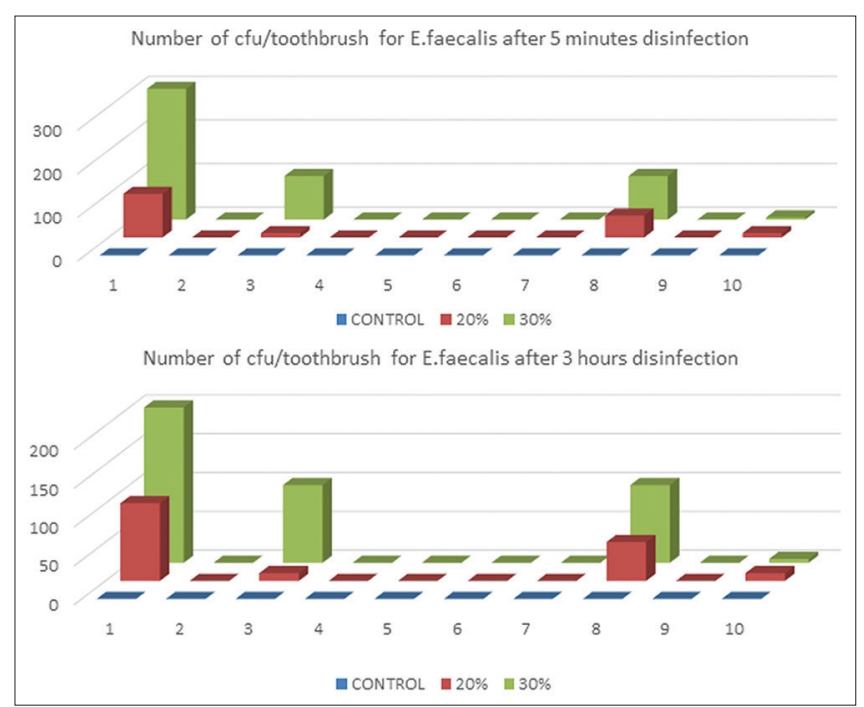

Figure 2: Difference in colony forming unit/toothbrush for Enterococcus faecalis at $20 \%$ and $30 \%$ concentration against control at 5 min and 3 $\mathrm{h}$ disinfection period

\begin{tabular}{|c|c|c|}
\hline Concentration level & Variables & $P$ \\
\hline $\mathrm{IIa}$ & L. acidophilus (3 $\mathrm{h}$ and $5 \mathrm{~min}$ ) & 0.027 \\
\hline Illb & L. acidophilus (3 $\mathrm{h}$ and $5 \mathrm{~min}$ ) & 0.011 \\
\hline
\end{tabular}

Table 3: Bonferroni adjusted Mann-Whitney test for
pairwise comparison

was aimed to reach the public community for the ease in preparation and as a way to recycle the dried-out leaves of guava.

The selection of microorganisms used in the present study was based on their involvement in development and progression of dental caries. S. mutans is the most common microorganism which has its role in the initiation of human dental caries $^{[12]}$ and L. acidophilus is responsible for progression of carious lesion rather than in initiation of the disease. ${ }^{[12,13]} E$. faecalis is the most common species that has been implicated in endodontic infections. ${ }^{[14]}$ Unfortunately, many of these organisms remain on the toothbrush and can reinfect our teeth, that is, every subsequent brushing introduces new bacteria into the oral cavity. ${ }^{[1]}$

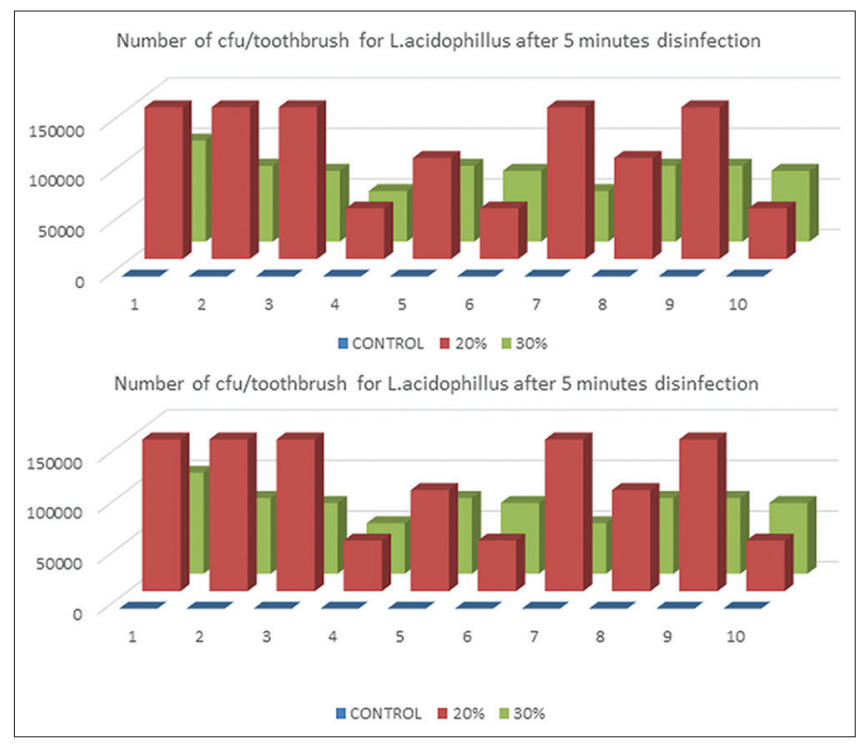

Figure 3: Difference in colony forming unit/toothbrush for Lactobacillus acidophilus at $20 \%$ and $30 \%$ concentration against control at $5 \mathrm{~min}$ and $3 \mathrm{~h}$ disinfection period

P. guajava (guava) is proven for its antimicrobial, antiparasitic, antitussive, hepatoprotective, antioxidant, antigenotoxic, antimutagenic, antiallergic, anticancer, and antihyperglycemic effects in medical field. ${ }^{[15]}$ In the field of dentistry, its antiplaque, antimicrobial, and anti-inflammatory properties are proven by various authors. ${ }^{[16,17]}$

Our present study shows a strong antibacterial activity of aqueous extracts of guava leaves in two different concentrations. Mehta et al. ${ }^{[10]}$ reported that as the concentration of the aqueous extract was increased, that is, from $5 \%$ to $20 \%$, there was an increase in the zone of inhibition. This was the reason to keep the concentrations of disinfectants prepared in the study at $20 \%$ and $30 \%$. Our present study showed an increase in antibacterial efficacy against L. acidophilus at both the disinfection periods when the concentration of the disinfectant was at $30 \%$ with a statistically significant result $(P<0.05)$ and the $20 \%$ and $30 \%$ concentration had a statistically significant reduction when compared with the control $(P<0.01$ for $20 \%$ and $P<0.05$ for $30 \%)$.

The disinfection period was kept at 5 min to evaluate the rapid antimicrobial activity of the extract and $3 \mathrm{~h}$ to evaluate any reduction in the antimicrobial activity as the disinfectant is a natural product and applicable for molecular deterioration. Our present study showed a statistically significant reduction of $L$. acidophilus from 5 min to 3 h at both $20 \%(P<0.027$ and $30 \%(P<0.011)$ concentrations. 
Vignesh, et al.: Guava leaf extract as toothbrush disinfectant

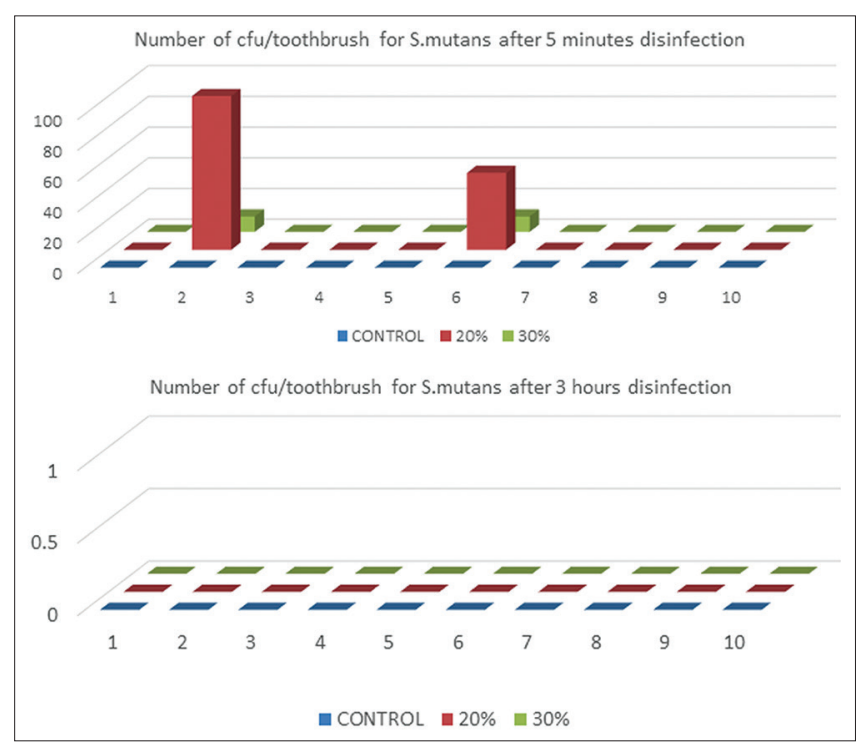

Figure 4: Difference in colony forming unit/toothbrush for Streptococcus mutans at $20 \%$ and $30 \%$ concentration against control at $5 \mathrm{~min}$ and 3 $\mathrm{h}$ disinfection period

The antibacterial activity of guava leaves is attributed to the presence of terpenes, ${ }^{[11]}$ flavonoids, ${ }^{[5,11]}$ and tannins. ${ }^{[18]}$ Barbalho et al. in 2011 identified eight flavonoids from guava fresh leaves out of which Guaijaverin has high potential to inhibit the growth of the $S$. mutans ${ }^{[19]}$ and the most highly abundant flavonoid present is quercetin. ${ }^{[20]}$ The antibacterial action of quercetin is probably due to the disruption of membrane and inactivation of extracellular proteins by forming irreversible complexes and prevents adhesive glucan formation disrupting the initial adhesion ${ }^{[15,21]}$ Guaijaverin binds to the cell surface proteins thereby decreasing the hydrophobicity. ${ }^{[15]}$ These flavonoids also interact with microbial membrane proteins, enzymes, and lipids, thereby altering cell permeability and permitting the loss of protons, ions, and macromolecules. ${ }^{[21]}$ Tannins can form hydrogen bonds with the protein contained in bacterial cells leading to a conformational change in the protein molecule causing denaturation of proteins. ${ }^{[18]}$ Terpenoids are membrane-active in nature causing sublethal injury of bacterial cell membranes thereby altering their permeability and affect the ability to adequately osmoregulate or exclude toxic materials. ${ }^{[22]}$

\section{CONCLUSION}

From the results of the current study, it could be concluded that:

a. Aqueous extracts of guava leaves can be used as a natural disinfectant for disinfecting contaminated toothbrushes as effective as $0.2 \%$ chlorhexidine b. Since the preparation of the aqueous extract is very simple, it could be used as an alternative organic product for disinfection of toothbrushes in households.

\section{Acknowledgments}

We would like to thank Mr. Arun from People's Diagnostic Laboratory for helping us in the microbiological analysis in the current study.

\section{Financial support and sponsorship}

Nil.

\section{Conflicts of interest}

There are no conflicts of interest.

\section{REFERENCES}

1. Karibasappa GN, Nagesh L, Sujatha BK. Assessment of microbial contamination of toothbrush head: An in vitro study. Indian J Dent Res 2011;22:2-5.

2. Nelson-Filho P, da Silva LA, Ds Silva RA, da Silva LL, Ferreira PD, Ito IY. Efficacy of microwaves and chlorhexidine on the disinfection of pacifiers and toothbrushes: An in vitro study. Pediatr Dent 2011;33:10-3.

3. Nagaraj A, Acharya S, Jeph V, Biswas G. Toothbrush contamination a review of Indian literature. Int J Dent Clin 2014;6:20-1.

4. Frazelle MR, Munro CL. Toothbrush contamination: A review of the literature. Nurs Res Pract 2012;2012:420630.

5. Garode AM, Waghode SM. Antibacterial activity of Psidium guajava Linn (Guava) leaves extracts on bacterial pathogens. Int J Bioassays 2014;3:1794-6.

6. Kraivaphan V, Boonyamanound L, Amornchat C, Trirantana T, Kraivaphan P. The effect of a mouthrinse containing Psidium guajava Leaf extract on gingivitis. J Dent Assoc Thai 1991;41:323-8.

7. Esimone CO, Nworu CS, Ekong US, Iroha IR, Okolin CS. A case for the use of herbal extracts in oral hygiene: The efficacy of Psidium guajava-based mouthwash formulations. Res J Appl Sci 2007;2:1143-7.

8. MB Pai, GM Prashant, KS Murlikrishna, KM Shivakumar, GN Chandu. Antifungal efficacy of Punica granatum, Acacia nilotica, Cuminum cyminum and Foeniculum vulgare on Candida albicans: An in vitro study. Indian J Dent Res 2010;21:334-36.

9. Moshrefi A. Chlorhexidine. J West Soc Periodontol Periodontal Abstr 2002;50:5-9.

10. Mehta VV, Rajesh G, Rao A, Shenoy R, B.H.M. Pai. Antimicrobial efficacy of Punica granatum mesocarp, Nelumbo nucifera Leaf, Psidium guajava Leaf and Coffea Canephora extract on common oral pathogens: An in-vitro study. J Clin Diagn Res 2014;8:ZC65-8.

11. Braga T, Dores R, Ramos C, Evangelista F, Tinoco L, Varotti F, et al. Antioxidant, antibacterial and antitumor activity of ethanolic extract of the Psidium guajava Leaves. Am J Plant Sci 2014;5:3492-500.

12. Krishnakumar R, Singh S, Subba Reddy VV. Comparison of levels of mutans streptococci and lactobacilli in children with nursing bottle caries, rampant caries, healthy children with 3-5 dmft/DMFT and healthy caries free children. J Indian Soc Pedod Prev Dent 2002;20:1-5.

13. Ravindran S, Chaudhary M, Gawande M. Enumeration of Salivary Streptococci and Lactobacilli in children with differing caries experiences in a rural Indian population. ISRN Plast Surg 2013;2013:16.

14. Cogulu D, Uzel A, Oncag O, Aksoy SC, Eronat C. Detection of Enterococcus faecalis in necrotic teeth root canals by culture and polymerase chain reaction methods. Eur J Dent 2007;1:216-21.

15. Ravi K, Divyashree P. Psidium guajava: A review on its potential as an adjunct in treating periodontal disease. Pharmacogn Rev 2014;8:96100

16. Fathilah AR. Piper betle L. and Psidium guajava L. in oral health maintenance. J Med Plant Res 2011;5:156-63.

17. Prabu GR, Gnanamani A, Sadulla S. Guaijaverin - A plant flavonoid as potential antiplaque agent against Streptococcus mutans. J Appl 
Vignesh, et al.: Guava leaf extract as toothbrush disinfectant

Microbiol 2006;101:487-95.

18. Mailoa MN, Mahendradatta M, Laga A, Djide N. Antimicrobial activities of tannins extract from guava leaves (Psidium guajava $\mathrm{L}$ ) on pathogens microbial. Int J Sci Technol Res 2014;3:236-41.

19. Barbalho SM, Farinazzi-Machado FM, de Alvares Goulart R, Brunnati AC, Otoboni AM, et al. Psidium guajava (Guava): A plant of multipurpose medicinal applications. Med Aromat Plants 2012;1:104.

20. Rattanachaikunsopon P, Phumkhachorn P. Contents and antibacterial activity of flavonoids extracted from leaves of Psidium guajava. J Med Plants Res 2010;4:393-6.

21. Ferrazzano GF, Amato I, Ingenito A, Zarrelli A, Pinto G, Pollio A. Plant polyphenols and their anti-cariogenic properties: A review. Molecules 2011;16:1486-507.

22. Jasmine R, Selvakumar BN, Daisy P. Investigating the mechanism of action of terpenoids and the effect of interfering substances on an Indian medicinal plant extract demonstrating antibacterial activity. Int J Pharm Stud Res 2011;2:19-24 